\title{
Contributions of Women's Participation in the Local Government of Bangladesh
}

\author{
Md. Mizanur Rahman \\ Research Division, Bangladesh Academy for Rural Development (BARD), Comilla, Bangladesh \\ Email: mizanbard@gmail.com
}

Received 17 June 2015; accepted 21 July 2015; published 24 July 2015

Copyright (C) 2015 by author and Scientific Research Publishing Inc.

This work is licensed under the Creative Commons Attribution International License (CC BY). http://creativecommons.org/licenses/by/4.0/

(c) (i) Open Access

\begin{abstract}
Union Parishad (UP) as a unit of rural local government of Bangladesh has a history of 145 years but women's representation was ensured only 2 decades ago. The paper is based on the argument that within the span of 2 decades, despite encountering huge challenges some women leaders (WLs) might have performed their role with their constrained participation in the UP. Against such a context, the paper is aimed at unraveling the research question: How did WLs perform in the UP amidst their challenges and constrained participation? The paper is based on hermeneutic phenomenological approach which was supported by case study, content analysis and observation methods. The findings of the paper revealed that having ensured their limited participation in the UP some women leaders were able to promote transparency and accountability, establish social justice and provide community services in the rural society.
\end{abstract}

\section{Keywords}

Participation, Women Leaders, Local Government, Union Parishad, Community Services, Bangladesh

\section{The Research Context and Problematic}

The Union Parishad (thereafter UP) is the lowest unit of local government (LG) in Bangladesh that began functioning in 1870 during the British colonial rule. Since the colonial era until 1976 there was no provision for women representation in the UP in Bangladesh. In a real sense, women's representation in the UP was ensured in the LG Ordinance of 1997, which made a provision of reservation of a one-third seats for women members. During the prolonged 145 (1870 to 2015) years of LG history, important development concerning women's representation took place within the last 18 years that spanned from 1997 to 2015. However within these 2 decades women leaders (thereafter WLs) strived to ensure their rights in the UP. Against such a backdrop this paper 
aimed at unraveling the research question: How did WLs perform in the UP amidst their challenges and constrained participation?

\section{Women's Representation in the Local Government in Bangladesh}

The British founded today's UP with the Village Chowkidary Act of 1870. The ending of British rule in India gave birth of two different states such as India and Pakistan in 1947. Afterwards, Bangladesh achieved independence and inherited LG systems from Pakistan in 1971. Since 1870 the functionaries of local government ${ }^{1}$ were always in the hands of males (Chowdhury et al., 1994: p. 6) and rights to vote in the local bodies were dependent on the educational qualification, possession of property and tax payment etc. (Smock, 1977: p. 117; Women for Women, 1992). However, women's representation in the political community was allowed through the Government of India Act in 1935 (Forbes, 2002) but based on the universal adult franchise, women for the first time took part in the election to the rural local bodies in 1956 (Rashiduzzaman, 1968; Inter-Parliamentary Union, 1987) and thereby only one female candidate was elected in the UP election of 1956 and 1969 during the Pakistan regime. In the first UP election of Bangladesh in 1973, out of 4352 UPs, only one woman was elected as the UP Chairman (Alam \& Begum, 1974: pp. 38-51). Afterwards, women's representation to the UP was enshrined by two presidential ordinances namely through Local Government Ordinance of 1976 and Municipal Ordinance of 1977, which for the first time provided a provision of nomination of 2 women members in the UP. Remarkable development regarding women's representation in LG took place during the Ershad regime ${ }^{2}$ through the Union Parishad Ordinance of 1983 that made a provision of nomination of three women members in the UP (Haque, 2003a; Khan, 2011; Khan \& Ara, 2006). A major breakthrough in the representation style of women in the UP was made in 1997, which provided a one-third reservation for women. By the UP act of 1997, in each UP, 3 seats are reserved for a women and accordingly one woman member is elected from three Wards, whereas 9 male members are elected from 9 Wards through direct election in the UP.

\section{Methodology Employed}

This paper is based on qualitative method. It was deemed that by using qualitative methods, lived and rich experiences, multiple realities, diverse dimensions, dynamics and benefits of participation of the WLs could be explored and thus to help unearth the research question properly, which cannot be obtained otherwise. To uncover the research question, hermeneutical phenomenological approach was adopted, which was substantiated by case study to enrich the findings obtained from interview. Author's own observation gained through his prolonged (more or less about 200 hours) field work has also been incorporated in this paper. Data were collected during July-December 2013. To support primary data some secondary data were also used. For phenomenological analysis data were arranged thematically. In order to incorporate diverse views data were collected from 19 UPs covering different socio-cultural zones ${ }^{3}$ of Bangladesh. Mostly the WLs were interviewed separately so that they can share their experiences and realities properly, whereas in few cases some male members of the UP, community members and leaders were also interviewed for having their perspectives and better understanding the problematic. The whole discussion was recorded with the informed consent of the participants and afterwards transcription was prepared into English from Bengali. In line with the research question, data were then organized into different thematic areas and thereafter reducing data from 21 themes, 4 themes were finalized through a rigorous process. For analyzing the essence or meaning of the textual descriptions obtained from the participants, content analysis method was adopted using the relevant literatures from research reports, books, journal articles through a heuristic search from library materials and online both.

${ }^{1}$ Here in this paper local government connotes rural local government, more specifically Union Parishad, the oldest rural local government body in Bangladesh. Till 1983, the only local government in Bangladesh was Union Parishad. In the last 145 years that spanned from 1870 till 2015, UP never loses it representative character and election was continued every 5 years alternate in UP amidst many ups and downs in Bangladesh society.

${ }^{2}$ Hussain Muhammad Ershad was one of the military rulers in Bangladesh. While he was the Chief of Army Staff of the Bangladesh Army, he declared Martial Law following a bloodless coup and became the Chief Martial Law Administrator in 1982. Afterwards he occupied the office of the President of Bangladesh from 1983 to 1990. During Ershad regime, following the suggestions of National Executive Committee for Administrative Reform and Reorganization (NICARR), he undertook substantive reform measures in the sphere of civil administration and local government system in Bangladesh.

${ }^{3}$ There are 7 divisions, 64 districts, 507 Upazilas and 4498 Union Parishads in Bangladesh. The sampled 19 UPs were selected covering 5 divisions and 7 districts of Bangladesh i.e. Chittagong, Comilla, Faridpur, Sylhet, Barisal, Bogra and Gaibandha districts. 
In qualitative research ${ }^{4}$, one of the major challenges is data reduction and make final conclusion from a huge data. In such exercise the researcher was ultimately able to deduct huge data synchronizing all those data into a holistic framework for analysis the study findings in order to answer the research question properly.

Due to dearth of the available literature the researcher deemed significant to delve into the benefits of participation from their own perspectives following the phenomenological approach. For fructifying the goal of the researcher, initially the researcher tried to establish a contact with the research participants. As the principal participants were the women leaders, so the researcher needed to maintain pre-fixed time so that they could understand the sincerity and feel a sense of obligation to respond quarries of the researcher. Then on meeting them the researcher tried to establish a good rapport and trust with them so that they can mentally turn on to share their lived experience without hesitation. During rapport and trust building stage the researcher collected some socio-economic and political profiles of the women leaders and thereafter the researcher tried to engage them in sharing their experience with the researcher. As soon the researcher finished collecting the short checklist the researcher then invites one by one to share their perceptions and experiences and sometimes the researcher also allows them participate responding in a group as well. In most cases the researcher discusses with the participants in the UP Complex.

Initially the researcher planned to collect data from 7 UPs from 7 divisions of Bangladesh. But as soon as the researcher started collecting data in Comilla he failed to move to other district due to severe political unrest of Bangladesh. Then the researcher decided to collect data from the women members of some UPs around Comilla district, where he works. After the researcher has obtained a commendable insight about the research question, he then visited to a few UPs in Chittagong and Sylhet Districts which are nearby district of BARD, Comilla. By this time some of the themes started repeating. As this was the author's Ph.D. dissertation, so the researcher tried to employ his highest efforts for data collection. By this time political crisis of Bangladesh aggravated further and author's approved leave period was about to terminate. Then the researcher observed that if he plans to collect data during holidays he can overcome the political problem and thus the researcher at last was able to cover 29 women leaders in 19 UPs from 5 socio-cultural zones of Bangladesh. The opposition started giving their Hartal $^{5}$ program on Mondays to Tuesday which made trip of the researcher to other district or division quite impossible. Then consulting the government websites the researcher collected the mobile numbers of the UP Chairmen and Women Members. Contacting personally with them the researcher completed his data collection in Bangladesh although he needed to reschedule his return ticket by 2 weeks but when the researcher was gathering the data he was quite happy to get rich data from a comprehensive plan despite huge repetition of the selected theme.

\section{Conceptual and Theoretical Underpinning of Participation}

In simple words, participation is a process through which stakeholders' influence and share control over priority setting, policy-making, resource allocations, and access to public goods and services. As a concept, it is not entirely new; in fact, it is as old as human civilization (Haque, 2003b). Various agencies, practitioners and academics have defined it from different perspectives. At first, the concept came as a concept of people's participation. Accordingly, the issue of people's participation has gained momentum in the realm of public administration and international development discourse in the last three decades. The scholars and practitioners of public administration and political science have considered people's participation in local development as an important part of democracy and development for both developed and developing countries (Roberts, 2004; Blair, 1981; Cooper, 1983; Fagence, 1977; White, 1994; Grote \& Gbikpi, 2002; Peters, 2001; Schumpeter, 1976; Meldon et al., 2004; Rahman, 2000).

Overtimes huge literatures evolve in the firmament of conceptual, definitional and theoretical labyrinth of participation. Likewise, some scholars suggest that participation may be viewed from two fundamental theoretical perspectives; political and developmental. In ultimate analysis, participation may be considered as a political and decision-making phenomenon. Cohen \& Uphoff (1977) viewed participation with regard to rural develop-

\footnotetext{
${ }^{4}$ Miles and Huberman (1984) commented that analysis methods were rarely reported enough detailed for the readers to follow how a researcher got from 3600 pages of field notes to the final conclusions. Again it was learnt that the data base they consulted in the preparation of the 1994 edition of Qualitative Data Analysis: An Expanded Sourcebook had more than tripled since publication of the first edition (Miles \& Huberman, 1984, 1994).

${ }^{5} \mathrm{Hartal}$ is a political weapon used by the political parties and other organized groups to enforce seizure or closure or shutting down of the state activities. It is a term in many South Asian languages for strike action, first used during the Indian Independence Movement. It is one of the means of mass protest often involving a total shutdown of workplaces, offices, shops, courts of law as a form of civil disobedience.
} 
ment as "people's involvement in decision making processes, in implementing program, their sharing in the benefits of development programs and their involvement in efforts to evaluate such program" (Oakley, 1991). Thus participation may be described as a vibrant collective activity of people in decision-making, implementing their plans/programs and projects and sharing benefits from the development process.

Pearse \& Stiefel (1979) define popular participation as "organized efforts to increase control over resources and regulative institution in given social situation, on the part of groups and movements of those hitherto excluded from such control” (Chowdhury, 1980). Uphoff (1987, quoted in Chowdhury, 1987) defines four types of participation: 1) Participation in decision making, in identifying, formulating alternatives, planning activities, allocating resources etc; 2) Participating in implementation, in carrying out activities, managing and operating programs, partaking of services; 3) Participating in evaluation of the activity and outcomes; and 4) Participation in economic, social, cultural or other benefits, individually or collectively. This definition emphasizes the components of people's participation and the mechanism of ensuring such participation with a view to exercising their control over the political, social and economic environment for their own advancements.

International aid agencies defined people's participation in a more comprehensive manner. Participation refers to the close involvement of the people from all walks of life irrespective of sex, race, group, caste, color and religion in economic, social, cultural and political decision-making process of an area (UNDP, 1993). According to the World Bank (2002), participation is the process through which stakeholders' influence and share control over priority setting, policy making, resource allocation and access to public goods and services. On the other hand, for the OECD, people's participation stands for partnership, which is built upon the basis of dialogue among the various actors, during which the agenda is jointly set, and local views and indigenous knowledge are deliberately sought and respected. This implies negotiation rather than the dominance of an externally set project agenda. Thus, according to the OECD, people become active actors in the development process instead of only being beneficiaries (OECD, 1997). The Human Development Report (UNDP, quoted in Mayo and Craig, 1995: p. 2) defines participation differently and according to them "participation refers to access to decision-making and power and economic participation".

The fundamental thought of participation is to provide local people with a significant role and decision-making power at the local level development programs that are designed for them and which affect their lives. Bhatnagar and Williams (1992: p. 6) opines that "Participation is a function of information through which people can come to share a development vision, make choices, and manage activities". Blair (2000) has identified a consequential formula of participation, that is, participation leads representation, representation ensures empowerment and empowerment gives benefits for all. Finally, all these improvements reduce poverty and enhance equity among all groups which leads the country to the way of good governance (Blair, 2000: p. 23). Therefore, participation could be defined both an end and a means (Oakley, 1991; Ahmad et al., 1998). As an end, participation lifts the marginalized people from being excluded to being in partnership with public institutions. As a means, it enables them to contribute to the development in a meaningful manner for their own, as well as for society's benefit (Ahmad et al., 1998). Thus, participation can be seen from two parameters, efficiency and empowerment. In the efficiency parameter, participation is considered a tool for achieving better project out comes. In the empowerment parameter, it is a process that enhances the capacity of individuals to improve their own lives, and it facilitates social change to the advantage of disadvantaged or marginalized groups (Cleaver, 1999). Therefore, reversing power is the key to participation.

Since early seventies different international organizations, scholars of public administration, sociology, political science and so on tried to define it and put emphasis on participation from various perspectives but the meaning of participation is still blurred and ambiguous (Ahmed, 1987; Quddus, 1994). Because of its amorphous nature of the term, Adnan et al. (1992: p. 51) suggest to "distinguish between the different ways in which the term might be understood or misunderstood". Participation is, however, not always effective. It can be passive, co-optive and as well as ditched if it is not property understood and nurtured. One may thus come across many types of participation. In summarized form we can say that over a long time the concept and meaning of participation undergo changes in its essences and paradigms.

\section{Contributions of the Women Leaders at the Grassroots}

In this section, women's contributions in the UP governance have been elucidated with textual description and analysis. Despite women's minuscule role in the UP some women members (WMs) having NGO background performed excellent role in the rural society as explained beneath sequentially. 


\subsection{Women Leaders Promoting Integrity in the UP}

Through the entry of women members into the structure of local governance, it was found that they were trying hard to establish transparency, accountability, honesty and sincerity in the sphere of UP affairs, which could be understood from the utterance of the Chairperson of the Jolla UP, Wazirpur Upazila, Barisal, who stated the following:

"As per government rules, when we undertook any development project in any ward, the respective male and female member need to serve as the head of the Scheme Selection Committee(SSC) and the adviser respectively and other respectable village elderly and few socio-cultural village elites also served in that committee but the main point here that due to the women members' involvement in the Parishad, transparency, accountability and participation of the people had increased a lot" (Chairperson, Jolla UP, 31 October 2013).

The above text implied that due to women's role transparency and accountability in the UP has enhanced immensely and thus community people have also encouraged taking part in the grassroots development process of the country.

In replying to a query about how people were getting benefits from the women members, the women Chairperson of the Manikdaha UP, Vanga Upazila, in the Faridpur district opined that "due to the entry into the women, transparency, accountability in the overall affairs of the UP had enhanced immensely."

Another woman member, Fatima Akhter Parul, from the Khadimpara UP, Sylhet, shared her experience in the following words:

"Yes we get VGD ${ }^{6}$ cards tantamount to male members but despite that people run after to get that card, especially when it is $\mathrm{VGF}^{7}$ we face lots of problem because poor people never loose hope to get it from me. You know sometimes when I could not give them VGD card I just give 100 taka from my own pocket" (Woman Member, Khadimpara UP, 28 September 2013).

An analysis of the above quotation from Fatima shows her respect for the voters and her accountability to them. Due to scanty resources in the UP, it is hardly possible to satisfy all of the demands of the general mass, so she chose an appropriate way to satisfy her compliance with the voters of her jurisdictional area. Thus she proved that she was accountable to her voters. Furthermore, this also shows how women members maintain their commitment with the community people. This is unique because she provided better services to her constituents and they also rewarded her when she contested the election for the second time. Khan (2009: p. 23) also found that nowadays, the Chairmen and male members are becoming more and more inclined to gradually open up to the women members and help in maintaining transparency and accountability in UP affairs.

Discussed with the Secretary of the Bijoypur Modham UP, he shared that:

"Women members are ensuing transparency, accountability and integrity while the beneficiaries of the old age pension holders came to the public bank for taking their benefits.” (Secretary, Bijoypur Modham UP, 21 August 2013).

It is really interesting to note that in a particular date the concerned WM need to provide such service being physically present at the bank premises to certify and attest the bills and prior to come to bank all beneficiaries are required to inform the date by the respective women member of that Wards. Thus by turn all 3 WMs need to perform such services one by one and thus they are maintaining transparency, accountability and integrity in providing safety net benefits.

During my elaborate discussion with the woman Chairman Manikdaha UP, Vanga Upazila, Faridpur District in some point of the conversations one of the villagers who was attending the discussion reiterated that "rela-

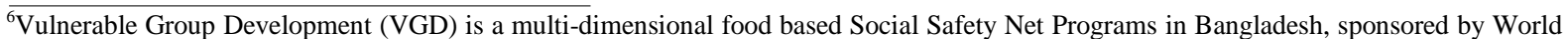
Food Program. The target group of the program is mainly destitute women covering landless and assetless women who are widowed, divorced, abandoned, having under-nourished children, lactating mothers and women with handicapped husband etc. In recent times, the program has moved from its role of relief provider to larger development role like providing training on life skills and income generating skills to women beneficiaries. The aim of the program is to enhance food and nutrition security of women and children through improved food consumption, education, skills development, livelihood diversification and risk mitigation. To achieve objective of VGD program, currently about 3.75 million beneficiaries from ultra-poor households are provided with the provision of monthly food ration of $30 \mathrm{~kg}$ of wheat or 25 $\mathrm{kg}$ of fortified wheat flour (atta, in Bangla) for a period of 24 months, and a package of development services for human capital development.

${ }^{7}$ VGF is an acronym for Vulnerable Group Feeding. The VGF program is one of the food-based social safety net programs in Bangladesh. It was created in the 1970s by the World Food Program (WFP) for emergency aid caused by disaster. Now the government provides food subsidy for the poorest under this program. The targets of the program are: 1) daily labourers whose income is low or irregular; 2) the landless or those that have less than 0.15 acres of land; 3 ) persons with disabilities or their wives; 4) poor women/men affected by natural disaster.
} 
tively women were sincere and their work quality were better than the man’s work”. The Chairman, Manikdaha UP has also agreed with that saying the following:

"When I assign any work to the female members I need not think about the quality but when I assigned any project to the male member, I must look into those projects”. (Chairman, Manikdaha UP, 31 October 2013).

The underlying fact behind it is that women are more sincere than that of men members. Due to their inherent positive and philanthropic mental make-up, Chairman being another woman found women member quite sincere and committed to their assigned work. Such perspective on women is also gauged by a male member of the Amratali UP, who firmly confirmed that stating that:

"Women are relatively more honest than the male members and there are less tendency and thinking for corrupt practices among the women members". (Male Member, Amratali UP, 25 September 2013).

It was learnt from the common people of the Chandpur UP, Boalmari, Faridpur district that male members usually took money ranging from 400 - 1500 Taka (5 - 20 US\$) $)^{8}$ while people came to them for asking various services from the UP such as benefits relating to old age pension, widow allowance, disabled people allowance; succession certificates and other services rendered by the UP. Women members generally rendered those services based on the rational judgment but women members were allowed to provide limited services for the poor people and therefore they were found unhappy for their not playing desired role for the poor people in the UP.

\section{Summary and Analysis}

By sharing information with the community people, women have promoted transparency and accountability and integrity in rural society. Women's pro-poor attitude towards sincerity and participatory governance helped ushering integrity in the rural society. Women's sincerity has been reflected and corroborated by various studies. Kaushik (1993: p. 6) found that women are more sincere, stable, committed, capable of hard work, and above all, not corrupt. Schein (1989: p. 154) (quoted in Genovese, 1993: p. 10) opines that "women's leadership has been linked with enhancing world peace, reducing corruption, and improving opportunities for the downtrodden. If women, as keepers of the values of social justice, nurturance, and honesty, are put in charge, then the conflicts, corruption and greed around us will go away". Such is the case is quite evident in the newly entrants women leadership in Bangladesh. Desai (1997: p. 53) describes how individual women have resisted the corruption that plagues Indians local government, used their budget carefully, and cleared the debts of their locality. Although women are born and brought up in a highly male dominated atmosphere but there are evidences that due to different socialization and life experience, women may simply be different from Men (Phillips, 1991; Molyneux, 1985). Evidence shows that "women bring to politics a different set of values, experiences and expertise (Phillips, 1995: p. 6). Scholars have found that in general male law makers are less likely to initiate and pass laws that serve women's and children's interest and they less often think about rape, domestic violence, women's health, and child care (Berkman \& O'Connor, 1993; Bratton \& Kerry, 1999; Childs \& Withey, 2004; SchwindtBayer, 2006; Swers, 1998; Taylor-Robinson \& Roseanna, 2003; Thomas, 1991). Chathuculam and John (2000: pp. 66-101) found that despite facing numerous problems in the LG of Kerala, women's performance on the basis of qualitative and quantitative indicators is in no way inferior to than that of male members. Drawing on experiences from other states of India it was found that the elected women members of the Panchayats bodies have shown startling performance, particularly in the sectors of health, education, access to basic services and in ensuring a significant change in the living conditions of the communities. Even in strong patriarchal culture these reserved women have encouraged to demonstrate their leadership (Kot, 2007). Women's participatory approach has other better ramifications in the society as well. Recent studies have shown that the political participation of women has positive effects on the country's prospect for development: for example countries with more women in parliament typically have lower levels of corruption even after we control for national income and other factors shown to affect corruption (World Bank, 2001). Moreover, it was empirically evident that where the influence of women in public life is greater, the level of corruption is lower and some scholars have also observed that women may have higher standard of ethical behavior and may be more concerned with common good (Dollar et al., 1999; Reiss \& Mitra, 1998; Glover, Minnette, Bumpus, \& Ciesla, 1997). There are evidences that rather than men, women tend to be more democratic and participatory in their leadership style than are men (Eagly \& Johnson, 1990) and women tend to be more collaborative in their leadership styles than men are (Rosenthal, 1998: p. 855). There are evidences that "women are more likely to exhibit cooperative, compassionate,

\footnotetext{
${ }^{8}$ One UD\$ $=77.78$ taka as of 22 March 2015. The figure is calculated more or less full digit deducting the fraction amount.
} 
and humane types of behaviors than men” (Schein, 1989: p. 154 quoted in Genovese, 1993).

\subsection{Women Leaders Are Providing Better Community Services}

Being imbibed with some intrinsic human values women leaders have accelerated providing various community services, which are directly affecting the wellbeing of poor rural women in today's Bangladesh ${ }^{9}$. Field data analysis revealed that women leaders are contributing enormously to improve community services in the UP. Replying to a question a male member from Amratali UP informed that women are serving the society in different ways. He noted that:

"All 3 women members are helping in distributing VGD cards, old age pension and VGF card, birth registration and many other things. When the beneficiaries of old age pension scheme withdraws money from the bank the women members are required to attest the form and sign with their seal. As they represent 3 wards, so when the beneficiaries of all those wards need to withdraw money from bank the women members need to be present always and thus they are serving the community". (Male Member, Amratali UP, 25 September 2013).

The above text testified that women leaders were rendering immense services to the rural communities. Amin \& Akhter (2005: pp. 6-7) found that in distributing VGF and VGD cards 60\% women members have been allowed to be fully involved; $25 \%$ have got partial involvement; and 15\% have got no opportunity of involvement. But I found that not only women leaders have integrated with distribution of VGD and VGF cards, they have also enhanced the number of beneficiaries, which can be grasped well by the following quotation from a woman member from the South Durgapur UP, Comilla Sadar, Comilla District, who described that:

"After we enter into the UP, the service delivery has improved a lot. In the previous days, the villagers get only 30 VGD cards, whereas now we distributed 120 VGD cards in just one ward, so whether we are doing good to them or not, they understand easily. We select the beneficiary very consciously, if the villagers see any slur to it, they just inform the Chairman immediately. We are available for the public as and when necessary and even it was 12 am at 0 hours". (Woman Member, South Durgapur UP, 26 August 2013).

Based on my field experienced I found that these women members were also involved in providing such type of safety nets for women and same was the case with maternal allowances. In line with it, a woman member from Wahedpur UP, Mirsarai mentioned that:

"In our society government has started maternal allowance in every village. In such activities women members' help and cooperation is a must for the smooth implementation of this program". (Woman Member, Wahedpur UP, 30 August 2013).

Obviously, the above quotations imply that women are providing community services to the women in the UP now. It was observed that women members were able to contribute immensely for improving the management of various safety net benefits in the UP. Due to the villagers' easy access to the women members, right selection of the applicants, their modest approach and their integrity, community people have found these women leaders enormously beneficial for them. Evidence shows that by ensuring selection of a fair list of eligible beneficiaries for Safety Net Programs, local government has contributed to increasing the access of the excluded groups (Sikder et al., 2011). Rahman (2005) found that engaging local communities proved better implementation of the development schemes at grassroots level due to ensured transparency and accountability in the UPs. These findings have also corroborated with Nazneen and Tasneem (2010) where they found that both the communities and women councilors value the role they play in implementing safety-net related programs and development projects, even though the responsibilities of the women councilors are not fully demarcated from those of men councilors.

\subsubsection{Empirical Evidence on the Community Services by the Women Leaders}

The following case will reveal the fact how women leaders are providing community services for rural women. During the researcher's field visit, a woman member from Amratali UP, Comilla shared her experience how she provided such community service to one woman victim, which is narrated below.

Nazma Akhter, woman member, Amratali UP, Comilla informed that as an aftermath of a trivial family feud,

\footnotetext{
${ }_{9}^{9}$ Now government of Bangladesh are providing various kinds of safety net programs for vulnerable poor people of the country and UP functionaries have been vested with the responsibility to distribute many of those safety net programs in the rural society. Old Age Pension, Vulnerable Group Development (VGD), Vulnerable Group Feeding (VGF), Maternal Allowances for Pregnant Mothers, Test Relief, Rural Maintenance Work (RMP), 40 Days Work for Seasonal Employment etc., are some safety net programs operated by the UP.
} 
one non-commissioned solder in military service one day bit severely his wife and demolished all valuables in the house. Doing that he went away to Dhaka. After that incident, the victim woman came to woman member and asked her help. Then the woman member advised the wife to collect the address of the higher authority of military services at Dhaka. After that she (woman member) sent a complaint against that man to the higher authority. And at the same time, she also talked over cell phone with that solder and requested to meet her immediately. The solder immediately came and informed her that if the Union Parishad did not withdraw the complaint against him, the authority would suspend him. Then she told the husband that if he stopped all these family violence and lived happily with his family then she would help him. After that the woman member took an undertaking from the husband where he proposed that he would never do such idiotic occurrence with his wife and family in the future. Then we informed again the higher authority about his current promise and thus served the woman member and saved the woman's family. From the innermost sense of humanity and community feelings, Nasima provided this community service for one of the constituent in her jurisdictional area [Retold by Nasima Akhter, Woman Member from Amratali UP, Comilla, 25 September 2013].

\subsubsection{Summary and Analysis}

Participation of women members has brought about a positive change in the rural salish ${ }^{10}$ and thus they help rural women get their social justice and better life. In absence of woman members, when women experienced violence in the village, there was no chance to observe the victim on behalf of woman members that time. Now when a woman became victim of physical assault by her husband, woman member can see and accordingly the charge can be framed by the salish council with evidential proof presented by the women leaders. When poor women sought assistance regarding family feuds or violence against women, these UP women member helped them get legal support from relevant sources, which were non-existent while women members were not in the UP. Examples of such community service provided by women leaders all over the world are galore. Siddiqee (2008) found that $77 \%$ women members assist the women of their area to get access to micro credit from various sources. It was evident that women had a special responsibility to represent the needs and interests of women (Waring, Greenwood, \& Pintat, 2000: p. 133; Sawer, 2002: p. 8). Buckley (1997: p. 173) also found that "women acted differently from their male colleagues and they are found less aggressive, less envious, more progressive, more productive, more pain-staking, scrupulous, conscientious, hard working, more pragmatic and opposed to war”. Johnson, Kabuchu, and Kayonga (2003) found that women participated more in community services at the local government. The same finding was also corroborated by Drage (2001), who found that women have a greater sense of social issues, well-being and welfare of their communities. It was also found that women members have contributed enormously in areas like housing, safety, clean water, sanitation, environment, and education, social implications of policies, health services, childcare, poverty alleviation and community development. Thomas (1991) and Thomas and Welch (1991) found that compared to men women are more likely to priories bills related to children, family, and women and health care, family policy, elder care, and social services (Little, Deen, \& Rebecca, 2001; Wangnerud, 2000; Skjeie, 1991, 2002; Solheim, 2000).

\subsection{Women Leaders Contributing to Social Justice through Rural Salish System}

Despite serious male domination women members have contributed to better governance by establishing social justice, which has been substantiated by the utterance of a school teacher of Kalirbazar UP who said that:

"Involvement of women has eased women get social justice. Previously when women became victims they could not tell their real problem to the male members but now these helpless victim women could easily share their painful saga to the women members" (A School Teacher, Kalirbazar UP, 27 August 2013).

The above text testified the fact that women members were of immense assistance for the women in the rural society. The involvement of the UP women members in the village court system facilitated better judgment. Due to such provision, women have got opportunity to flourish their leadership potential and thus they could represent and uphold the needs of the women through a structured arrangement.

Replying to the relevant question a woman member from Amratali UP, Comilla immediately replied that:

"Due to entry of the woman member in to UP, the women folk are getting huge benefit from us because when they experience male oppression and violence they immediately come to us for remedy and they demand justice to us but they never go to male members for seeking justice against oppression and violence against woman.

\footnotetext{
${ }^{10}$ Salish refers to informal local arbitration council for resolution of petty disputes conducted by the UP representatives.
} 
Sometimes we went to the Upazila Women and Children Affairs Officer for taking legal advice for violence against women". (Woman Member, Amratali UP, 25 September 2013).

Women members are trying to establish justice to the villagers through their active participation in the rural salish process. Siddiqee (2008) found that $66 \%$ women member participated in salish on regular basis. Amin \& Akhter (2005: p. 6) found that 75\% women members have taken part in salish and judgment of the UP as like as the male members; $15 \%$ women members reported that they are at times called in to attend the salish and judgment; and $10 \%$ have reported that they have never been called in to attend the same.

When I asked what and how general public were benefitted by the presence of these women members in the Parishad, Fatima Akhter Parul, a Woman Member from Khadim Para UP stated that:

"I do not know how general public are being benefited by the inclusion of women members in the Parsishad but I can firmly assure you that women would get enormous benefits by us. Especially in the village salish where women members remain present the victim woman can share her personal experiences or opinions or grievances to us easily without hesitation and with enhanced courage and will force. Previously when women members were not in the Parishad, they never get courage to open their mouth before the male villagers and members during the local arbitration/dispute resolution process. At that time women became more victims by the judgment given by the male villagers but now the situation has completely changed due to the involvement of women UP members in the Parishad". (Woman Member, Khadimpara UP, 28 September 2013).

Women's participation in the salish process has immensely benefitted the rural women, which was not possible when women members were non-existed in the parishad. Therefore, women's participation in the salish encouraged victim women to seek remedy for their grievances, injustice and violence caused by the male.

I employed a long discussion session with the male members in the Wahedpur UP, Mirersarai where I wanted to know how women members were contributing in the rural society now-a-days. One male member answered my question saying that:

"When a woman falls prey to victim and gets oppressed by her husband or anyone, women member can interview and see everything how her husband or others tortured her personally checking the cut mark in her body but it was never possible for a male member". (Woman Member, Wahedpur UP, 30 August 2013).

Through analysis of the above utterance it is understood that women members in the UP are trying utmost to establish social justice by improving the outcome of the rural salish. Before their entry into the UP, male members never can see the women victim and based on their hearsay or hearing from others, the salish council provided judgment but after their inclusion in the salish process now women members have resorted their prerogatives to see in their own eyes the cut marks or emblem of the physical torture done to them by their husband or other actors and being direct witnesses of the physical assaults, the women leaders are contributing to establishing improved social justice in the rural society.

\subsubsection{A Glaring Evidence of How WMs Established Social Justice in the Community}

Parul shared her experience with the author concerning how she was able to win the love of the common villagers by playing a role in the village salish. She elaborated that once she attended a village salish where she come to know that a young man forcibly raped a young woman. Realizing the significance of such a sensitive incident in the context of Bangladesh she pointed out that as the young man just spoiled the young woman with force and cruelty, she thought that without finishing salish and giving justice for such issue she would not leave from salish. She told that she called her husband there so that he could accompany her if it took late hours to finish the judicial procedure. She also requested some village elderly to remain present there so that they could provide due judgment to that case. She informed that almost 150 villagers were present there to help her and it took several hours to finish the whole judicial procedure. Then the juries unanimously decided that as the young man put the women in extreme shame and it would be very tough for that victim woman to get marry with anyone because all villagers already came to know this, so it was decided that the young man should have to marry that girl on that particular night. Then the juries summoned an official match maker to register this marriage following proper religious fanfares and rituals. When everything finished, it was $3 \mathrm{am}$. While the judicial procedures were going on, no male member was present there in the salish.

\subsubsection{Summary and Analysis}

From the textual narratives and case studies of the WLs it was evident that they are providing better services in many ways. In distributing the assigned safety net program to the UP, women members played formidable roles 
in selection of applicants based on rational judgments and strived to enhance the coverage bargaining with their male counterparts. Through maintaining an informal and friendly relationship with the villagers the women members are extending their all out supports in providing immense services to the villagers i.e. birth and death registration, succession certificates, various safety net benefits. Whereas in some cases male members provide such services on cash nexus but women members never claim anything rather they are facilitating to obtain those services to the community people without any harassment and monetary involvement. The topmost significance credited to women leaders' performance was that these WLs were striving to bring quality governance amidst accomplishing their regular household and reproductive role and challenges posed by the primordial patriarchal social structure.

The conduct of the salish is a glaring example of the community service of the woman members in her jurisdictional area. Such an act of social justice shows that woman have proper capacity to deal with life-related matters with proper dignity and honour. Through this case we can understand that woman members can perform their social commitment and responsibility with a strong hand and ensure the rule of law in the society. Thus having ensured with an enabling environment and supportive legal frame the UP women members have contributed to deliver social justice and good governance at the local level. There are other ramifications of such a case which demonstrates that she has an aggressive attitude to this extremely male-dominated patriarchal society, where she also considers herself as a victim, so she thinks that the rapist should not go unpunished rather by providing punishment she has ventilated her wrath and anger on the irrational draconian patriarchal social norm. Therefore, when she got an opportunity to take revenge through such a wrongdoing or misdeeds done by male domination and masculinity, she left no stone unturned to deal with it with an iron hand. Obviously men and women both live in a specific culture-bound, value-laden society, where all norms, values, actions, thoughts and beliefs are properly governed and applicable in line with that specific more of that culture. According to the social norms of Bangladesh, the judgment provided by the salish committee might be a culturally-appropriate decision. However, viewed from the substantive rationale it can be easily understood how awful it might be for a woman to endure her whole life being the wife to a rapist. Therefore, the pivotal question lies here is how will she suffer for the rest of her life, especially if her husband take revenge on her for a forceful marriage? Therefore, Parul's judgment concerning the rape case could not be supported at all; it axiomatically and unquestionably calls for necessary value changes in the society, where men and women can both enjoy the same rights and privileges without any discrimination.

\section{Conclusion}

Following the hermeneutic phenomenological approach supported by in-depth case study, observation and content analysis method, the paper attempted to answer the research question such as: How did WLs perform in the UP amidst their challenges and constrained participation? Through a rigorous analysis and in line with the author's research question, it is evident that some women leaders have ensured transparency, accountability and integrity in the overall UP governance, while some are providing extensive community services and bringing about transformative changes and development at the grassroots. Some WLs are found to be promoting the interests of women at the UP level and thus they are striving to ensure social justice in the UP through playing their role in the village court (salish). Here women members' social service for establishing social justice and rendering culturally suitable judgments in the rural society demands special mention. Strengthening the women's role in the rural society necessitates doable mechanism of value changes with suitable policy directives in Bangladesh.

\section{Acknowledgements}

Mr. Rahman defended his Ph.D. dissertation in the Graduate School of Public Administration (GSPA) of the National Institute of Development Administration (NIDA) on 22 July, 2014. The author would like to express his profound gratitude to his Ph.D. supervisor Professor Dr. Juree Vichit Vadakan for giving her valuable comments to develop the paper.

\section{References}

Adnan, S., Barrett, A., Alam, S. M. N., \& Brustinow, A. (1992). People’s Participation, NGOs and the Flood Action Plan: An Independent Review. Dhaka: Research and Advisory Services \& Oxfam-Bangladesh. 
Ahmad, A. K. F., Sarker, A. E., \& Ahmad, M. U. (1998). Participatory Development, Local Government and Rural Realities in Bangladesh: Some Preliminary Observations. Report of the Bergen-Dhaka Administrative Development Project, Department of Public Administration, Dhaka: University of Dhaka.

Ahmed, T. (1987). Decentralization and People’s Participation in Bangladesh: A Political Perspective. Comilla: Bangladesh Academy for Rural Development (BARD).

Alam, B. A., \& Begum, R. A. (1974). Violence and Union Parishad Leadership: A Few Statistics. Local Government Quarterly, 8.

Amin, R., \& Akhter, S. (2005). Women Participation in Local Government and Social Integration in Rural Bangladesh. Paper Presented in Workshop on Enlarging Citizen Participation and Increasing Local Autonomy in Achieving Societal Harmony, Network of Asia-Pacific Schools and Institutes of Public Administration and Governance (NAPSIPAG) Annual Conference 2005, Beijing, 5-7 December 2005.

Berkman, M. B., \& Robert E. O’Connor (1993). Do Women Legislators Matter? Female Legislators and Sate Abortion Policy. American Political Quarterly, 21, 102-124. http://dx.doi.org/10.1177/1532673X9302100107

Bhatnagar, B., \& Williams A. C. (Eds.) (1992). Participatory Development and the World Bank. World Bank Discussion Papers No. 183, Washington DC: World Bank. http://dx.doi.org/10.1596/0-8213-2249-4

Blair, H. W. (1981). Government at the Grass-Roots. Pacific Palisades, CA: Palisades Publishers.

Blair, H. W. (2000). Participation and Accountability at the Periphery: Democratic Local Governance in Six Countries. World Development, 28, 21-39. http://dx.doi.org/10.1016/S0305-750X(99)00109-6

Bratton, K. A., \& Kerry L. H. (1999). Agenda Setting and Legislative Success in State Legislatures: The Effects of Gender and Race. Journal of Politics, 61, 658-679. http://dx.doi.org/10.2307/2647822

Buckley, M. (1997). Adaptation of Soviet Women’s Committee: Deputies’ Voices from “Women of Russia”. In M. Buckley (Ed.), Post Soviet Women: From the Baltic to Central Asia (pp. 157-185). Cambridge: Cambridge University Press. http://dx.doi.org/10.1017/CBO9780511585197.011

Chathuculam, J., \& John, M. S. (2000). Empowerment of Women Panchayat Members: Learning from Kerala (India). Journal of Women's Studies, 6, 66-1010.

Child, S., \& Withey, J. (2004). Women Representing Acting Women: Sex and the Signing of Early Day Motions in the British Parliament. Political Studies, 52, 552-564.

Chowdhury, A. K. M. K. (1980). Administrative Framework and the Actual Procedure for Project Appraisal in Bangladesh. In M. Sirajuddin (Ed.), Project Management: A Compilation of Lecture Materials. Dhaka: Ministry of Planning.

Chowdhury, L. H. (1987). Local Self-Government and Its Reorganization in Bangladesh. Dhaka: National Institute of Local Government-NILG.

Chowdhury, N., Begum, H. A., Islam, M., \& Mahtab, N. (Eds.) (1994). Women and Politics. Dhaka: Women for Women.

Cleaver, F. (1999). Paradoxes of Participation: Questioning Participatory Approaches to Development. Journal of International Development, 11, 597-612.

http://dx.doi.org/10.1002/(SICI)1099-1328(199906)11:4<597::AID-JID610>3.0.CO;2-Q

Cohen, J. M., \& Uphoff, N. (1977). Rural Development Participation: Concepts and Measures for Project Design, Implementation and Evaluation. New York: Cornell University.

Cooper, T. L. (1983). Citizen Participation. In D. L. Thomas (Ed.), Organization Theory and Management. Public Administration and Public Policy/20, New York: Marcel Dekker, Inc.

Desai, N. (1997). Negotiating Political Space: Indian Women’s Movement and Political Participation. In V. Poonacha (Ed.), Women, Empowerment and Political Parties (pp. 46-60). Mumbai: Research Centre for Women Studies, SNDT Women's University.

Dollar, D., Fisman, R., \& Gatti, R. (1999). Are Women Really the Fairer Sex? Corruption and Women in Government. Policy Research Report on Gender and Development, Working Paper Series No. 4, World Bank.

Drage, J. (2001). Women in Local Government in Asia and The Pacific: A Comparative Analysis of Thirteen Countries. Report for the ESCAP, 34 .

Eagly, A. H., \& Johnson, B. T. (1990). Gender and Leadership Style: A Meta Analysis. Psychological Bulletin, 108, $233-256$. http://dx.doi.org/10.1037/0033-2909.108.2.233

Fagence, M. (1977). Citizen Participation in Planning. Oxford: Pergamon.

Forbes, G. (2002). Women of Character, Grit and Courage: The Reservation Debate in Historical Perspective. In L. Sarker, K. Sharma, \& D. L. Kasturi (Eds.), Between Tradition, Counter Tradition and Heresy. Delhi: Rainbow Publishers.

Genovese, M. A. (Ed.) (1993). Women as National Leaders. London, New Delhi: Sage Publication. 
Glover, S. H., Minnette A., Bumpus, J. E. L., \& Ciesla, J. R. (1997). Reexamining the Influence of Individual Values on Ethical Decision Making. Journal of Business Ethics, 16, 1319-1329. http://dx.doi.org/10.1023/A:1005758402861

Grote, J. R., \& Gbikpi, B. (2002). From Democratic Government to Participatory Governance. In J. R. Grote, \& B. Gbikpi (Ed.), Participatory Governance: Political and Social Implications (pp. 17-34). Opladen: Leske and Budrich.

Haque, M. A. (2003a). Gram Sarker Act: An Evaluation (in Bengali). Publish in the Daily Banglabazar on 14 December 2003.

Haque, M. S. (2003b). Reinventing Governance for Performance in South Asia: Impact on Citizenship Rights. International Journal of Public Administration, 26, 941-964. http://dx.doi.org/10.1081/pad-120019354

Inter-Parliamentary Union (1987). Distribution of Seats between Men and Women in National Assemblies. Geneva: IPU.

Johnson, D., Kabuchu, H., \& Kayonga, S. V. (2003). Women in Ugandan Local Government: The Impact of Affirmative Action. Gender and Development, 11, 8-18. http://dx.doi.org/10.1080/741954365

Kaushik, S. (1993). Women and Panchayat Raj. New Delhi: Har-Anand Publication.

Khan, M. M. (2011). Local Government in Bangladesh: Some Contemporary Issues and Practices. Dhaka: A. H. Publishing House.

Khan, M. M. R. and Ara, F. (2006). Women, Participation and Empowerment in Local Government: Bangladesh Union Parishad Perspectives. Asian Affairs, 29, 73-100.

Khan, Z. R. (2009). LGSP-LIC Study of Women's Participation in Local Development in the LIC Districts in Bangladesh. Dhaka: Local Government Division, GOB.

Kot, L. S. (2007). Women in Rural Democracy-A Changing Scenario. Vikas Samvad Fellowship 2007, Bhopal: People’s College of Medical Science and Research Centre.

Little, T. H., Deen, D., \& Rebecca, E. D. (2001). A View from the Top: Gender Differences in Legislative Priorities among State Legislative Leaders. Women and Politics, 22, 29-49. http://dx.doi.org/10.1300/J014v22n04_02

Mayo, M., \& Craig, G. (Eds.) (1995). Community Empowerment: A Reader in Participation and Development. London: Zed Books.

Meldon, J., Kenny, M., \& Walsh, J. (2004). Local Government, Local Development and Citizen Participation: Lesson from Ireland. In R. W. R. Lovan, M. Murry, \& R. Shaffer (Ed.), Participatory Governance: Planning, Conflict Mediation and Public Decision Making in Civil Society. Farnham: Ashgate Publishing.

Miles, B. M., \& Huberman, A. M. (1984). Qualitative Data Analysis-A Source Book for New Method. Thousand Oaks, CA: Sage.

Miles, B. M., \& Huberman, A. M. (1994). Qualitative Data Analysis—An Expended Source Book (2nd ed.). Thousand Oaks, CA: Sage.

Molyneux, M. (1985). Mobilization without Emancipation? Women's Interests, the State, and the Revolution. Feminist Studies, 11, 227-254. http://dx.doi.org/10.2307/3177922

Nazneen, S., \& Tasneem, S. (2010). Legitimacy Enhances Capacity. Issue: 40 Capacity.org (Bulletin).

Oakley, P. (1991). Projects with People-The Practice of Participation in Rural Development. Geneva: ILO.

OECD (1997). Evaluation of Programs Promoting Participatory Development and Good Governance: Synthesis Report. Paris: Development Assistance Committee (DAC) Expert Group on AID Evaluation, OECD.

http://www.oecd.org/dac/evaluation/dcdndep/35019452.pdf

Pearse, A., \& Stifel, M. (1979). Inquiry into Participation-A Research Approach, Popular Participation Program. Geneva: United Nations Research Institute for Social Development.

Peters, B. G. (2001). The Future of Governing. Lawrence, KS: University Press of Kansas.

Phillips, A. (1991). Engendering Democracy. University Park, PA: Pennsylvania State University Press.

Phillips, A. (1995). The Politics of Presence: The Political Representation of Gender, Ethnicity and Race. Oxford, UK: Clarendon Press.

Quddus, M. A. (1994). People’s Participation through Grassroots Level Organizations. In A. Salehuddin, \& S. J. A. Zahid (Ed.), Strategies and Issues in Local Level Planning in Bangladesh. Comilla: BARD.

Rahman M. M. (2000). Politics and Development of Rural Local Self-Government in Bangladesh. Delhi: Devika Publication.

Rahman, H. Z. (2005). Engaging on Good Governance: A Search of Entry Points. Dhaka: Power and Participation Research Centre (PPRC).

Rashiduzzaman, M. (1968). Politics and Administration in the Local Councils: A Study of Union and District Councils in East Pakistan. London: Oxford University Press.

Reiss, M. C., \& Mitra, K. (1998). The Effects of Individual Difference Factors on the Acceptability of Ethical and Unethical Workplace Behaviors. Journal of Business Ethics, 17, 1581-1593. http://dx.doi.org/10.1023/A:1005742408725 
Roberts, N. (2004). Public Deliberation in an Age of Direct Citizen Participation. American Review of Public Administration, 34, 315-353. http://dx.doi.org/10.1177/0275074004269288

Rosenthal, C. S. (1998). Determinants of Collective Leadership: Civic Engagement, Gender or Organizational Norms? Political Science Quarterly, 51, 847-868.

Sawer, M. (2002). The Representation of Women in Australia: Meaning and Make-Believe. Parliamentary Affairs, 55, 5-18. http://dx.doi.org/10.1093/parlij/55.1.5

Schein, V. E. (1989). Would Women Lead Differently? In W. Rosenbach, \& R. Taylor (Eds.), Contemporary Issues in Leadership (pp. 134-160). Boulder, CO: Westview.

Schumpeter, G. (1976). Capitalism, Socialism and Democracy. London: Unary University Press.

Schwindt-Bayer, L. A. (2006). Still Supermadres? Gender and the Policy Priorities of Latin American Legislators. American Journal of Political Science, 50, 570-585. http://dx.doi.org/10.1111/j.1540-5907.2006.00202.x

Siddiqee, M. S. H. (2008). Gender and Good Governance Issues in Local Government of Bangladesh: A Baseline Report of Extension Phase (RETA-6008). Dhaka: Research and Evaluation Division, BRAC.

Sikder, T., Engali, J., Byrne, S., \& Tabet, T. (2011). Socially Inclusive Local Governance-Case Study: Sharique-Bangladesh. Dhaka: Inter-Cooperation, Institute of Development Studies, The Democratization and Local Government Network.

Skjeie, H. (1991). The Rhetoric of Difference: On Women’s Inclusion into Political Ethics. Politics and Society, 19, 233263.

Skjeie, H. (2002). Credo on Difference-Women in Parliaments in Norway. In A. Karam (Ed.), Women in Parliament: Beyond Numbers (pp. 183-89). Stockholm: International IDEA.

Smock, A. C. (1977). Bangladesh: A Struggle with Tradition and Poverty. In J. Z. Giele, \& A. C. Smock (Ed.), Women: Roles and Status in Eight Centuries (Chap. 3, pp. 81-126). New York, London, Sydney, Toronto: John Wiley \& Sons.

Solheim, B. O. (2000). On Top of the World: Women's Political Leadership in Scandinavia and Beyond. Westport, CT: Greenwood Press.

Swers, M. L. (1998). Are Women More Likely to Vote for Women's Issue Bills than Their Male Colleagues? Legislative Studies Quarterly, 23, 435-448. http://dx.doi.org/10.2307/440362

Taylor-Robinson, M. M., \& Roseanna M. H. (2003). Do Women Legislators Have Different Policy Priorities than Their Male Colleagues? A Critical Case Test. Women and Politics, 24, 77-101. http://dx.doi.org/10.1300/J014v24n04_04

Thomas, S. (1991). The Impact of Women on State Legislative Priorities. The Journal of Politics, 53, 958-976. http://dx.doi.org/10.2307/2131862

Thomas, S., \& Welch, S. (1991). The Impact of Gender on Activities and Priorities of State Legislators. The Western Political Quarterly, 44, 445-456. http://dx.doi.org/10.2307/448788

UNDP (1993). Human Development Report 1993. New York: UNDP.

Uphoff, N. (1987). Beating the Odds: Lessons for Development Project Planning and Implementation from Gal Oya. Sri Lanka. (Unpublished Draft)

Wangnerud, L. (2000). Testing the Politics of Presence: Women’s Representation in the Swedish Riksdag. Scandinavian Political Studies, 23, 67-91. http://dx.doi.org/10.1111/1467-9477.00031

Waring, M., Greenwood, G., \& Pintat, C. (2000). Politics: Women’s Insights. Inter-Parliamentary Union.

White, S. A. (1994). The Concept of Participation: Transforming Rhetoric to Reality. In S. A. White, K. S. Nair, \& J. Ascroft (Ed.), Participatory Communication: Working for Change and Development. London: Sage.

Women for Women (1992). Women in Politics and Decision Making in the Late Twentieth Century: A United Nations Study. Prepared by the Division for the Advancement of Women, xii-xiii.

World Bank (2001). Engendering Development. In N. H. Stern (2002), on the occasion of the Public Lecture on The Investment Climate, Government and Inclusion in Bangladesh, organized by the Bangladesh Economic Association on 8 January 2002, Dhaka.

World Bank (2002). Promoting Social and Public Accountability-Participatory and Community Based Monitoring and Evaluation. World Bank: Uganda Videoconference. 